\begin{tabular}{c} 
International Journal of Engineering \& Technology, 7 (3) (2018) 1664-1667 \\
International Journal of Engineering \& Technology \\
SPC \\
Website: $\begin{array}{c}\text { ww. sciencepubco.com/index.php/IJET } \\
\text { doi: } 10.14419 / \text { ijet.v7i3.15557 } \\
\text { Research paper }\end{array}$ \\
\hline
\end{tabular}

\title{
Solar radiation map of Jordan governorates
}

\author{
Saad S. Alrwashdeh ${ }^{1 *}$, Falah M. Alsaraireh ${ }^{1}$, Mohammad A. Saraireh ${ }^{1}$ \\ ${ }^{1}$ Mechanical Engineering Department, Faculty of Engineering, Mutah University, P.O Box 7, Al-Karak 61710 Jordan \\ *Corresponding author E-mail: saad.alrwashdeh@mutah.edu.jo
}

\begin{abstract}
The solar energy potential in Jordan is enormous as it lies within the solar belt of the world with average solar radiation between 4 and 8 $\mathrm{KWh} / \mathrm{m} 2$, which implies a potential of 1400-2300 GWh per year annually. Electricity demand in Jordan plays a significant role in the high amount of energy consumption to cover the needs of heating, cooling, lighting, etc. For that, the availability of the solar radiation information becomes essential to help in the design and building of the solar energy application. In this study, a solar radiation map is provided of all Jordan governorates.
\end{abstract}

Keywords: Energy; Electrical Demand; Solar Radiation MAP.

\section{Introduction}

Jordan consumption of primary energy is mainly composed of crude oil and imported electricity. But Jordan is blessed with an abundance of solar energy which is evident from the annual daily average solar irradiance (average insolation intensity on a horizontal surface) ranges between $4-8 \mathrm{kWh} / \mathrm{m}^{2}$, which is one of the highest in the world. This corresponds to a total annual of 1400$2300 \mathrm{kWh} / \mathrm{m}^{2}$; with the average sunshine duration is more than 300 days per year [1-7]. Nowadays, renewable energy systems are being utilized extensively to generate electricity due to its positive features [8-13].

Through various equipment have been invited to measure the incident solar radiation at a given location, due to high cost of maintenance and the resulting inaccuracies and error has required the development of predictive correlation to estimate solar radiation using whether parameter. For this, the astronomical distance between the sun and the earth as well as the angles and heights at which solar rays incident on earth are vital [14].

Various models have been developed to estimate global solar radiation on the horizontal surfaces using sunshine hour data [15-26]. The sun is the driving force for all atmospheric processes. Solar radiant intensity is the expression of that input of energy upon the planet. Therefore, the ability to understand and quantify its value and distribution accurately is important in the initial understanding and modeling of any other thermodynamic or dynamic process in the earth-ocean-atmosphere system. Unfortunately, however, too little is known about the spatial and temporal distribution of incoming solar radiation. A more complete and precise description of that distribution will prove usefulness to many fields of study that rely on atmospheric energy input, such as agricultural, architectural, and engineering planning [14], [19], [27-30]. For these reasons, analysis of the solar radiation distribution in India - a state with a relatively high loading of input radiation and relatively high spatial and temporal variability - is both important and relevant.

Most studies on solar radiation were conducted in Amman city. A correlation for predicting the average global solar radiation incident on a horizontal surface in Amman was developed. In another study, solar radiation data were measured and assessed for Amman [31-
33]. In this study, the map of the solar radiation of Jordan governorates presented in order to simplified the selection of the solar applications.

\section{Geographical and meteorological data}

Jordan lies within a latitude of $32^{\circ}$ North and longitude of $36^{\circ}$ East. Jordan has more than 300 sunny days a year, providing a sunshine duration of about 3125 hours/year. Figure 1 represents the number of sunshine days of Jordan for each month.
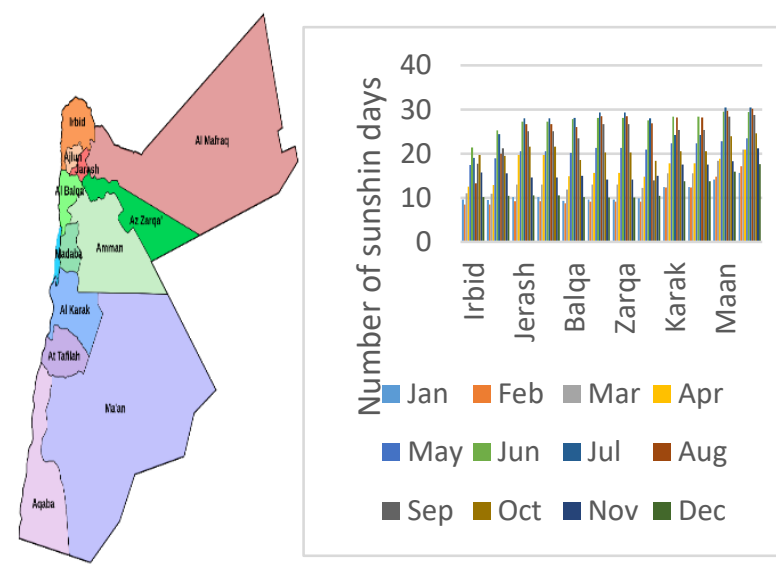

Fig.1: The Jordan Governorates: Irbid, Ajloun, Jerash, Mafraq, Balqa, Amman, Zarqa, Madaba, Karak, Tafilah, Maan and Aqaba, and the Number Of Sunshine Days Per Month For Each of Jordan Governorates [1].

According to the solar atlas of Jordan figure. 2, the country is divided into five regions. The Southern region representing Ma'an and Aqaba area, which has the highest solar isolation in the country and has the lowest values of diffuse irradiance. The annual average daily global irradiance is between $6-7 \mathrm{kWh} / \mathrm{m}^{2}$. The Eastern region representing the semi desert and the (badia) remote area with an annual daily between $5.5-6 \mathrm{kWh} / \mathrm{m}^{2}$. The middle region with an average global irradiance at $4.5-5 \mathrm{kWh} / \mathrm{m}^{2}$, but with the highest annual daily average of diffused irradiance. The Northern region with the 
annual daily average global irradiance of about $5.5 \mathrm{kWh} / \mathrm{m}^{2}$. The Western region representing the Jordan Valley area, situated below sea level and with an average annual daily global irradiance below $4.5 \mathrm{kWh} / \mathrm{m}^{2}$.

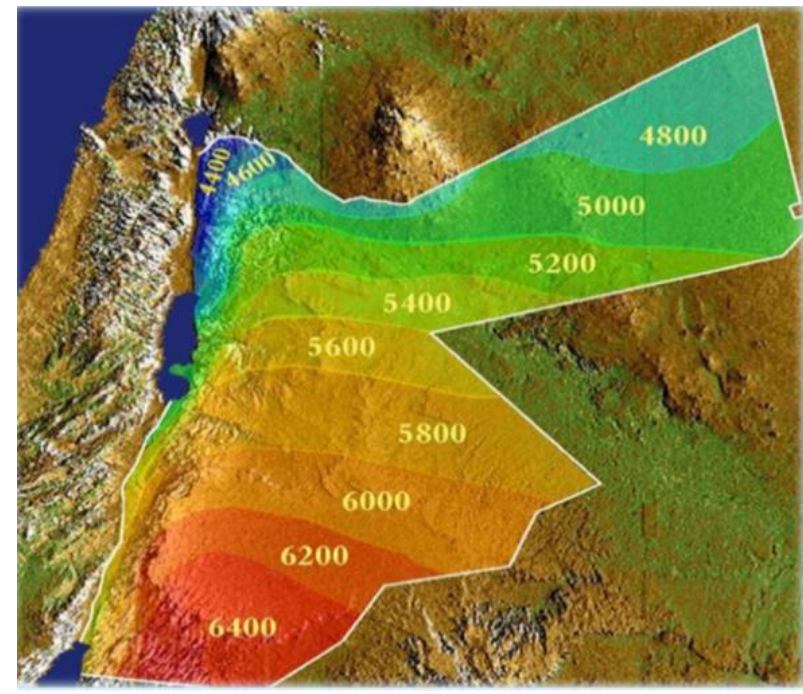

Fig. 2: Global Solar Radiation Map of Jordan in Wh/M2/Day.

\section{Solar radiation theory}

The sun is the largest energy source of life while at the same time it is the ultimate source of most of renewable energy sources. In this work, a map of solar radiation of Jordan governorates will be designed. The calculation is based on the average day of each month using the following formulas [17], [34-36].

The declination is calculated by using:

$\delta=23.45 \sin \left(2 \pi \frac{284+n}{365}\right)$

The sunset hour angle $\omega$ s can be calculated by using:

$\omega \mathrm{s}=\cos ^{-1}(-\tan \emptyset \tan \delta)$

The daily extraterrestrial radiation on a horizontal surface, Ho, can be calculated by using:

$H_{0}=\frac{24 \times 3600 G_{s e}}{\pi}\left(1+0.033 \cos \frac{360 n}{365}\right) \times\left(\cos \emptyset \cos \delta \sin \omega+\frac{\omega \pi}{180} \sin \emptyset \sin \delta\right.$

Where

$\mathrm{Gsc}=1367 \mathrm{~W} / \mathrm{m}^{2}$

The monthly average clearness index, KT, can be calculated by using:

$K_{T}=H / H_{0}$

Where

$\mathrm{H}=9864000 \mathrm{~J} / \mathrm{m}^{2}$

The monthly average daily diffuse radiation $\mathrm{Hd}$ can be calculated by using:

Since $\omega \mathrm{s} \leq 81.4^{\circ}$ and $0.3 \leq \mathrm{KT} \leq 0.8$

$H_{d}=1.391-3.560 K_{T}+4.189 K_{T}^{2}-2.137 K_{T}^{3}$

The incidence angle depends on the following parameters: geographical position, time (day of year as well as time of day) and plane orientation.
Tilt angle $\beta$ and an azimuth angle $\gamma$ of the plane will be defined the following way: Take a horizontal surface and incline it to the south (in positive direction) or to the north (in negative direction) by $\beta$ and rotate it then to the west (in positive direction) or to the east (in negative direction) by taking into consideration that the time will be given in standard time, we will have to determine at first the corresponding solar time. In a second step we can calculate the hour angle $\omega$ and declination $\delta$. With these angles and with the plane tilt angle $\beta$ and the plane azimuth angle $\gamma$ we can determine the incidence angle $\theta$ according to the following formula

$\cos \theta=\sin \delta \sin \phi \cos \beta-\sin \delta \cos \theta \sin \beta \cos y+\cos \delta \cos \delta \cos \beta \cos \omega+\cos \delta \sin \varnothing \sin \beta \cos y) \cos \omega+\cos \delta \sin \beta \beta \sin \gamma y \sin \omega$

In some special cases this formula adopts a simpler form. First, if we consider horizontal surfaces, then the incidence angle will be independent of the plane azimuth angle.

$\cos \theta=\sin \delta \sin \emptyset+\cos \delta \sin \varphi \cos \omega$

Second, for vertical surfaces facing towards south in the northern hemisphere the equation transforms into:

$\cos \theta=-\sin \delta \sin \emptyset+\cos \delta \sin \varphi \cos \omega$

\section{Result and discussion}

Solar irradiation is the sun's radiant energy incident on a surface per unit area, expressed in a unit of $\mathrm{Wh} / \mathrm{m} 2$ and calculated based on an average daily basis for a given month. Figure. 3 shows the irradiation on the horizontal plane in $\mathrm{Wh} / \mathrm{m} 2 /$ day for all Jordan governorates. It is noted that Aqaba has the highest irradiation on the horizontal plane among all other Jordan governorates. While the lowest irradiation on the horizontal plane was in Ajloun. The highest irradiation on the horizontal plane comes during June for all Jordan governorates with an average irradiation of $8300 \mathrm{Wh} / \mathrm{m} 2 /$ day approximately. While the lowest irradiation comes during December with an average irradiation of $2800 \mathrm{Wh} / \mathrm{m} 2 /$ day approximately.

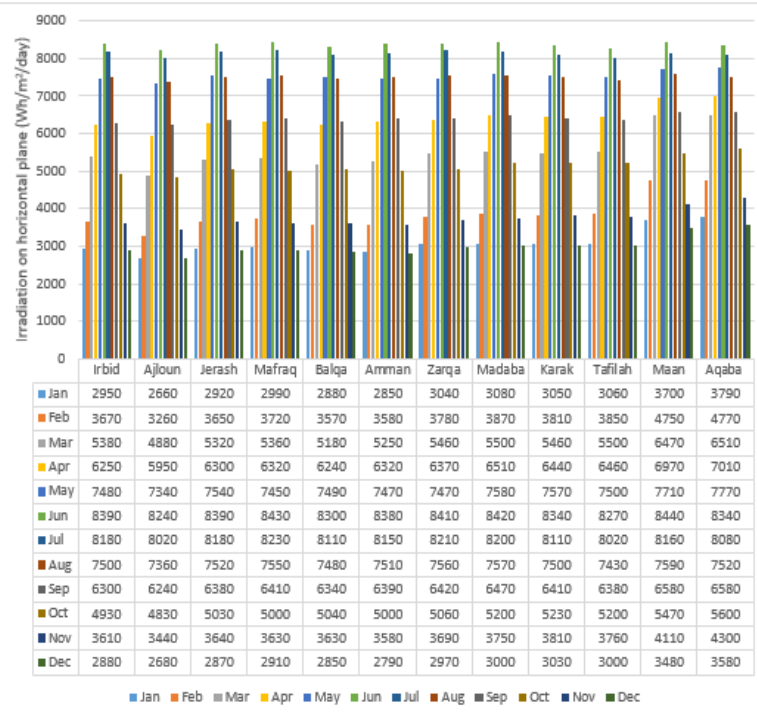

Fig. 3: Solar Irradiation on the Horizontal Plane of Jordan Governorates in $\mathrm{Kwh} / \mathrm{M}^{2} /$ Day.

Solar radiation estimation has been carried out from the beginning of operation of solar converters in order to guide scientific and commercial applications. In this sense, the main interest is in estimating the solar irradiation collected on tilted surfaces, for which the usual numerical estimation is based on global and diffuse radiation on a horizontal plane. Figure. 4 shows the irradiation on optimally inclined plane in $\mathrm{Wh} / \mathrm{m}^{2} /$ day of Jordan governorates. It can be ob- 
served that Aqaba has the highest irradiation on the optimum inclined plane comparing to all Jordan governorates. Reversibly, the lowest irradiation on the optimam inclined plane was in Ajloun. As well as the irradiation on the horizontal plane, the maximum irradiation on the optimally inclined plane comes during June for all Jordan governorates with an average irradiation of $7500 \mathrm{Wh} / \mathrm{m}^{2} /$ day approximately. While the lowest irradiation comes during December with an average irradiation of $4300 \mathrm{Wh} / \mathrm{m}^{2} /$ day approximately.

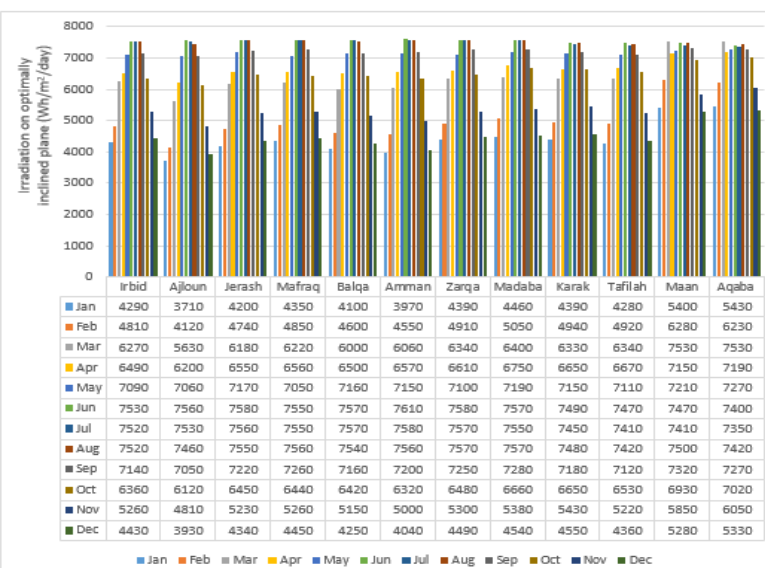

Fig. 4: Solar Irradiation on the Optimally Inclined Plane of Jordan Governorates in $\mathrm{Kwh} / \mathrm{M}^{2} / \mathrm{Day}$.

Direct Normal Irradiance is the amount of solar radiation received per unit area by a surface that is always held perpendicular to the rays that come in a straight line from the direction of the sun at its current position in the sky. Typically, we can maximize the amount of irradiance annually received by a surface by keeping it normal to incoming radiation. This quantity is of particular interest to concentrating solar thermal installations and installations that track the position of the sun. Figure. 5 illustrates the direct normal radiation in $\mathrm{Wh} / \mathrm{m} 2 /$ day of Jordan governorates. It can be noted that Aqaba and Maan have the maximum direct normal radiation comparing to all Jordan governorates with an average of $7300 \mathrm{Wh} / \mathrm{m} 2 /$ day. Opposite to that, the lowest direct normal radiation was in Ajloun. The maximum direct normal radiation comes during June for all Jordan governorates with an average irradiation of $8500 \mathrm{Wh} / \mathrm{m} 2 /$ day approximately. While the lowest direct normal radiation comes during December with an average irradiation of $4200 \mathrm{Wh} / \mathrm{m} 2 /$ day approximately.

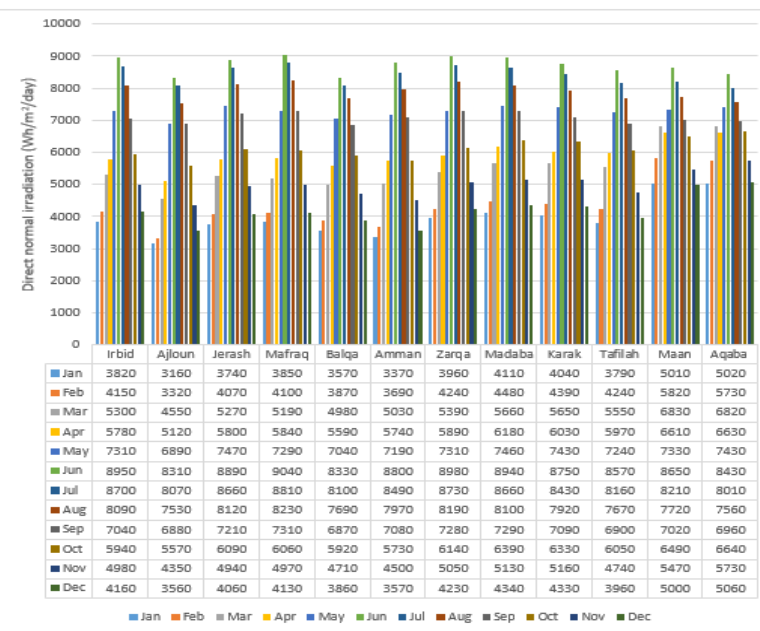

Fig. 5: Solar Direct Normal Radiation of Jordan Governorates in $\mathrm{Kwh} / \mathrm{M}^{2} /$ Day.

One of the methods for increasing the thermal efficiency of any type of collector is to use the optimum tilt angle. This is due to the fact that the orientation and tilt angle of a solar collector are the two most important factors usually considered in solar energy system design. Figure. 6 shows the monthly optimum inclination angle in the degree to be used for the solar applications in Jordan governorates. It is noted that the monthly optimum inclination angle of January in all Jordan governorates is around $55^{\circ}$ and it is started to decrease until reach $0.0^{\circ}$ in June where the maximum solar radiation can be achieved. After that it is started to increase to the same value of $55^{\circ}$ with decreasing in the solar radiation.

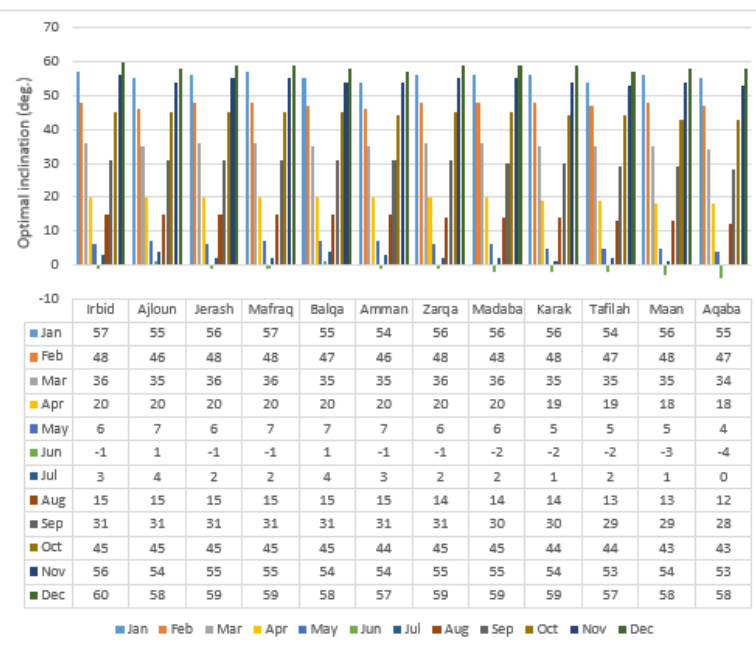

Fig. 6: Monthly Optimum Inclination Angle of Solar Application.

\section{Conclusion}

This paper presents a solar radiation map based on solar irradiation assessment and calculation for Jordan governorates. Validation of these models was performed by mathematical calculation. Correspondingly, from the result we could highlight several conclusions:

- Aqaba has the highest irradiation on the horizontal plane among all other Jordan governorates with a value of 6160 $\mathrm{Wh} / \mathrm{m}^{2} /$ day. While, Ajloun has the lowest irradiation on the horizontal plane with a value of $5420 \mathrm{Wh} / \mathrm{m}^{2} /$ day.

- Aqaba has the highest irradiation on the optimum inclined plane among all other Jordan governorates with a value of $6790 \mathrm{Wh} / \mathrm{m}^{2} /$ day. While, Ajloun has the lowest irradiation on the horizontal plane with a value of $5940 \mathrm{Wh} / \mathrm{m}^{2} /$ day

- Aqaba and maan have the highest irradiation on the optimum inclined plane among all other Jordan governorates with a value of $6670-6780 \mathrm{Wh} / \mathrm{m}^{2} /$ day. While, Ajloun has the lowest irradiation on the horizontal plane with a value of 5620 $\mathrm{Wh} / \mathrm{m}^{2} /$ day

- The maximum production expected from the solar application comes in June with an optimum tilt angle of $0^{\circ}$ approximately.

The results emphasize that the study presented might be utilized for the calculation of solar irradiation specific to the location chosen to select the optimum application for using to gain energy.

\section{References}

[1] Al-Najideen, M.I. and S.S. Alrwashdeh, Design of a solar photovoltaic system to cover the electricity demand for the faculty of Engineering- Mu'tah University in Jordan. Resource-Efficient Technologies, 2017. 3(4): p. 440-445. https://doi.org/10.1016/j.reffit.2017.04.005.

[2] Alsaad, M.A., Solar radiation map for Jordan. Solar \& Wind Technology, 1990. 7(2): p. 267-275. https://doi.org/10.1016/0741983X(90)90096-K

[3] Al-Soud, M.S. and E.S. Hrayshat, A $50 \mathrm{MW}$ concentrating solar power plant for Jordan. Journal of Cleaner Production, 2009. 17(6): p. 625-635. https://doi.org/10.1016/j.jclepro.2008.11.002.

[4] Alzoubi, H.H. and A.A. Alshboul, Low energy architecture and solar rights: Restructuring urban regulations, view from Jordan. Renewable Energy, $2010 . \quad 35(2): \quad$ p. $333-342$ https://doi.org/10.1016/j.renene.2009.06.017. 
[5] Alrwashdeh, S.S., Assessment of Photovoltaic Energy Production at Different Locations in Jordan. International Journal of Renewable Energy Research 2018. 8(2).

[6] Alrwashdeh, S.S., Map of Jordan governorates wind distribution and mean power density. International Journal of Engineering \& Technology, $2018 . \quad 7(3): \quad$ p. $1495-1500$. https://doi.org/10.14419/ijet.v7i3.14326.

[7] Alrwashdeh, S.S., Comparison among Solar Panel Arrays Production with a Different Operating Temperatures in Amman-Jordan. International Journal of Mechanical Engineering and Technology, 2018 9(6): p. 420-429.

[8] Alrwashdeh, S.S., et al., Neutron radiographic in operando investigation of water transport in polymer electrolyte membrane fuel cells with channel barriers. Energy Conversion and Management, 2017. 148 p. 604-610. https://doi.org/10.1016/j.enconman.2017.06.032.

[9] Alrwashdeh, S.S., et al., In Operando Quantification of Three-Dimensional Water Distribution in Nanoporous Carbon-Based Layers in Polymer Electrolyte Membrane Fuel Cells. ACS Nano, 2017. 11(6): p. 5944-5949. https://doi.org/10.1021/acsnano.7b01720.

[10] Ammari, H.D., S.S. Al-Rwashdeh, and M.I. Al-Najideen, Evaluation of wind energy potential and electricity generation at five locations in Jordan. Sustainable Cities and Society, 2015. 15: p. 135-143. https://doi.org/10.1016/j.scs.2014.11.005

[11] Saad S. Alrwashdeh, et al., Investigation of Water Transport in Newly Developed Micro Porous Layers for Polymer Electrolyte Membrane Fuel Cells. Applied Microscopy, 2017. 47(3): p. 101-104. https://doi.org/10.9729/AM.2017.47.3.101.

[12] Saad S. Alrwashdeh, et al., Improved Performance of Polymer Electrolyte Membrane Fuel Cells with Modified Microporous Layer Structures. Energy Technology, 2017. 5(9): p. 1612-1618. https://doi.org/10.1002/ente.201700005.

[13] Alrwashdeh, S.S., et al., Investigation of water transport dynamics in polymer electrolyte membrane fuel cells based on high porous micro porous layers. Energy, 2016. 102 p. 161-165. https://doi.org/10.1016/j.energy.2016.02.075.

[14] Beckman, J.A.D.a.W.A., Solar Engineering of Thermal Processes. Fourth Edition ed. Soalr Energy.2013, Hoboken, New Jersey: John Wiley \& Sons, Inc.

[15] Bahadori, A. and C. Nwaoha, A review on solar energy utilisation in Australia. Renewable and Sustainable Energy Reviews, 2013.18: p. 1-5. https://doi.org/10.1016/j.rser.2012.10.003.

[16] 1Demain, C., M. Journée, and C. Bertrand, Evaluation of different models to estimate the global solar radiation on inclined surfaces. Renewable Energy, 2013.50 p. 710-721.

[17] El-Sebaii, A.A., et al., Global, direct and diffuse solar radiation on horizontal and tilted surfaces in Jeddah, Saudi Arabia. Applied Energy, 2010. 87(2): p. 568-576. https://doi.org/10.1016/j.apenergy.2009.06.032.

[18] Good, C., I. Andresen, and A.G. Hestnes, Solar energy for net zero energy buildings - A comparison between solar thermal, PV and photovoltaic-thermal (PV/T) systems. Solar Energy, 2015. 122. p. 986-996. https://doi.org/10.1016/j.solener.2015.10.013.

[19] Hoffmann, W., PV solar electricity industry: Market growth and perspective. Solar Energy Materials and Solar Cells, 2006.90(18-19): p. 3285-3311.

[20] Schibuola, L., M. Scarpa, and C. Tambani, Calculation procedure to improve the assessment of photovoltaic generation in solar maps. Energy Procedia, 2017.122: p. 475-480. https://doi.org/10.1016/j.egypro.2017.07.295.

[21] MacDougall, H., S. Tomosk, and D. Wright, Geographic maps of the impact of government incentives on the economic viability of solar power. Renewable Energy, 2018.122: p. 497-506. https://doi.org/10.1016/j.renene.2017.12.108.

[22] Kanters, J., M. Wall, and E. Kjellsson, the Solar Map as a Knowledge Base for Solar Energy Use. Energy Procedia, 2014.48 p. 1597-1606.

[23] Pevtsov, A.A., L. Bertello, and P. MacNeice, Effect of uncertainties in solar synoptic magnetic flux maps in modeling of solar wind. Advances in Space Research, 2015.56 (12): p. 2719-2726.

[24] Kanters, J. and M. Wall, A planning process map for solar buildings in urban environments. Renewable and Sustainable Energy Reviews, 2016.57: p. 173-185. https://doi.org/10.1016/j.rser.2015.12.073.

[25] Besarati, S.M., et al., The potential of harnessing solar radiation in Iran: Generating solar maps and viability study of PV power plants. Renewable Energy, 2013.53: p. 193-199. https://doi.org/10.1016/j.renene.2012.11.012.

[26] Munzhedzi, R. and A.B. Sebitosi, Redrawing the solar map of South Africa for photovoltaic applications. Renewable Energy, 2009. 34(1): p. 165-169. https://doi.org/10.1016/j.renene.2008.03.023.
[27] Badran, O.O., Study in industrial applications of solar energy and the range of its utilization in Jordan. Renewable Energy, 2001. 24(3-4): p. 485-490. https://doi.org/10.1016/S0960-1481(01)00032-5.

[28] Huang, B.J., et al., Solar cell junction temperature measurement of PV module. Solar Energy, 2011. 85(2): p. 388-392. https://doi.org/10.1016/j.solener.2010.11.006.

[29] Khahro, S.F., et al., Evaluation of solar energy resources by establishing empirical models for diffuse solar radiation on tilted surface and analysis for optimum tilt angle for a prospective location in southern region of Sindh, Pakistan. International Journal of Electrical Power \& Energy Systems, 2015.64: p. 1073-1080. https://doi.org/10.1016/j.ijepes.2014.09.001.

[30] Vougioukalakis, G.C., et al., Contributions to the development of ruthenium-based sensitizers for dye-sensitized solar cells. Coordination Chemistry Reviews, 2011255 (21-22): p. 2602-2621. https://doi.org/10.1016/j.ccr.2010.11.006.

[31] Hamdan, M.A., Solar radiation data for amman. Applied Energy, 1994. 47(1): p. 87-96. https://doi.org/10.1016/0306-2619(94)900337.

[32] Hijazin, M.I., The diffuse fraction of hourly solar radiation for Amman/Jordan. Renewable Energy, 1998. 13(2): p. 249-253. https://doi.org/10.1016/S0960-1481(97)00082-7.

[33] Alsaad, M.A., Characteristic distribution of global solar radiation for Amman, Jordan. Solar \& Wind Technology, 1990. 7(2): p. 261-266. https://doi.org/10.1016/0741-983X(90)90095-J.

[34] El-Kassaby, M.M., Monthly and daily optimum tilt angle for south facing solar collectors; theoretical model, experimental and empirical correlations. Solar \& Wind Technology, 1988. 5(6): p. 589-596. https://doi.org/10.1016/0741-983X(88)90054-9.

[35] Le Roux, W.G., Optimum tilt and azimuth angles for fixed solar collectors in South Africa using measured data. Renewable Energy, 2016.96 Part a p. 603-612.

[36] Moghadam, H. and S.M. Deymeh, Determination of optimum location and tilt angle of solar collector on the roof of buildings with regard to shadow of adjacent neighbors. Sustainable Cities and Society, 2015.14 p. $215-222$. 